\title{
УПРАВЛІННЯ ЛОГІСТИЧНИМИ БІЗНЕС-ПРОЦЕСАМИ ПІДПРИЄМСТВ ТОРГІВЛІ: ПРОБЛЕМИ ТЕОРІЇ ТА ПРАКТИКИ
}

\author{
Міщук Ігор Пилипович \\ доктор економічних наук, доцент \\ Львівський торговельно-економічний університет (м. Львів, Україна) \\ ORCID ID: 0000-0001-5661-0164 \\ igmislog@ukr.net \\ Марій Ольга Тарасівна \\ аспірант \\ Львівський торговельно-економічний університет (м. Львів, Україна) \\ ORCID ID: 0000-0002-5499-1298 \\ igata_omurfamatia@ukr.net
}

\begin{abstract}
У роботі наведено результати логіко-сутнісного аналізу поняття «бізнес-процес» в системі процесного управління підприємствами торгівлі, встановлено ключову роль виконуваної в межах бізнес-процесу функції як чинника, що визначає типологію бізнес-процесів підприємств торгівлі, уточнено сутність, ознаки та типові переліки логістичних бізнеспроцесів підприємств оптової та роздрібної торгівлі, визначено необхідність їх регламентації задля впровадження у вітчизняну управлінську практику.
\end{abstract}

Ключові слова: підприємство торгівлі, процесний підхід, бізнес-процеси, логістична фуункиія, логістичний бізнеспроцес, модель управління бізнес-процесами

DOI: https://doi.org/10.32845/bsnau.2019.4.29

Постановка проблеми. Посилення конкурентних позицій суб'єктів торговельної діяльності в Україні в сучасних умовах значною мірою визначається впровадженням засад, принципів, інструментарію логістичного менеджменту та імплементацією й подальшою реалізацією в практичну діяльність прийнятих на цьому базисі рішень щодо ефективних схем організації логістичних потоків у ланцюгах просування товарів до споживачів. Ключовою умовою забезпечення ефективності інтегрованих логістичних ланцюгів, як відомо, вважається формування кожним задіяним у процесах руху в просторі та часі наскрізного товарного потоку суб'єктом господарювання, зокрема - оптовим або роздрібним підприємством, адаптованої до специфіки відповідних товарів системи логістики, а також - забезпечення оптимальної міжсуб'єктної взаємодії під час транзакційних процесів. Як у першому, так і в другому випадку одним з напрямів реалізації зазначених завдань може стати використання можливостей системного та процесного підходів, що передбачає зосередження уваги на побудові комплексної, відповідним способом організованої та структурованої системи пов'язаних між собою і з зовнішнім економічним середовищем логістичних бізнес-процесів кожного (в тому числі - торговельного) підприємства. Використання в умовах загострення конкуренції та зростання невизначеності змін зовнішнього середовища орієнтованої на бізнес-процеси моделі управління набуло актуальності в основних галузях народногосподарського комплексу України завдяки спроможності процесно-орієнтованого підходу забезпечити підвищення ефрективності діяльності та досягнення стратегічних цілей підприємств.

Аналіз останніх досліджень і публікацій. Питання змісту, форм сучасної торгівлі, видового різноманіття її суб'єктів в умовах ринкових механізмів господарювання і забезпечення ефрективної організації діяльності торговельних підприємств були предметом дослідження таких провідних вітчизняних і зарубіжних науковців, як В. Апопій, П. Балабан, Б. Берман, Б. Брагін, Г. Джоунз, М. Леві, Л. Лігоненко, А. Ма-

заракі, М. Чорна та ін. Теоретичні засади логістики та практичні аспекти організації логістичних формувань й управління комплексом логістичної діяльності підприємств торгівлі розглядали Д. Бауерсокс, Дж. Джонсон, В. Дибська, Б. Єсенькін, М. Кіршина, К. Ковальов, В. Колодін, К. Рутковські, В. Сергєєв, Дж. Сток, О. Торндорф та ін. Питання управління підприємствами на засадах процесного підходу, реінжинірингу бізнес-процесів підприємств та корпорацій висвітлено в працях Б. Андерсона, Р. Гарднера, М. Портера, М. Хаммера, Н. Харінгтона, Дж. Чампі, А.-В. Шеєра, О. Виноградової, С. Ілляшенка, І. Маркіної, О. Полінкевич, В. Рєпіна; при цьому безпосередньо проблематика сутності логістичних бізнес-процесів підприємств, їх особливостей на підприємствах торгівлі та розробки механізмів Т. зв. логістичного управління ними в тій чи іншій мірі аналізувалась у публікаціях Н. Ільченко [1], В. Алькеми [2], Н. Бойко [3], І. Кривов'язюка [4], Є. Крикавського [5], Т. Лазоренко [6], О. Ольшанського [7], П. Павловського [8], А. Петрової [9], І. Поповиченка [10], О. Солодкої [11], Л. Фролової [12] та ін.

Разом $з$ тим, слід відзначити наявність певних суперечностей в трактуванні самого поняття «логістичні бізнес-процеси», а також ігнорування авторами наявності значних розбіжностей у видовому різноманітті, змісті та способах реалізації логістичних бізнес-процесів підприємств оптової та роздрібної торгівлі. Тому, вважаємо, існує потреба більш детального теоретичного аналізу та практичної адаптації засад та інструментарію управління бізнес-процесами підприємств торгівлі у сфері логістики, ефективність логістичних бізнес-процесів у якій стає одним із актуальних чинників ринкового успіху залучених до ланцюгів постачань товарів суб'єктів господарювання.

Формулювання цілей статті. Метою статті є теоретичне узагальнення та уточнення сутності та змісту логістичних бізнес-процесів підприємств торгівлі, а також формулювання окремих практичних рекомендацій з удосконалення управління логістичними бізнес-процесами підприємств торгівлі. 
Методи дослідження. У дослідженні були використані методи: систематизації та узагальнення - при аналізі нормативних документів та теоретичних джерел; логіко-сутнісний - при визначенні та уточненні сутності терміну «бізнеспроцес»; системний - при побудові авторської моделі управління бізнес-процесами та дослідженні наукових підходів до визначення сутності й типології логістичних бізнес-процесів; абстрактно-логічний - для визначення рекомендацій щодо формування переліку логістичних бізнес-процесів для підприємств оптової та роздрібної торгівлі.

Виклад основного матеріалу. Аналіз публікацій вітчизняних і зарубіжних авторів засвідчує стійку активізацію уваги науковців і практиків до використання в умовах нестійкої економічної ситуації в Україні та загострення внутрішньогалузевої конкуренції можливостей процесного підходу до управління діяльністю торговельних підприємств. Загалом, основні ідеї процесного підходу пов'язані з можливостями зміцнення конкурентних переваг підприємства на ринку та забезпечення його стабільної діяльності у стратегічній перспективі за рахунок управління господарською діяльністю підприємства як сукупністю бізнес-процесів, адже «...бажаний результат досягається ефективніше, коли діяльністю і відповідними ресурсами управляють як процесами» [13].

Процесний підхід розглядає бізнес як сукупність бізнес-процесів, поняття яких в економічній теорії та практиці виводиться із розуміння більш загального поняття процесу як послідовного виконання певних функціональних операцій, спрямованих на досягнення визначеного результату, або ж як «...стійкої, цілеспрямованої сукупності взаємопов'язаних видів діяльності, яка за визначеною методикою трансформує входи у виходи» [14]. Попри наявність такого чіткого методичного базису, трактування похідного від нього поняття «бізнес-процес» в наукових працях суттєво «розмивається», адже трактується і як суто економічна категорія, і як структурний елемент бізнесу (господарської діяльності), і як спосіб вирішення завдань бізнесу (послідовність, алгоритми виконання функціональних дій, операцій), і як комплекс функціональних трансфрормацій (процедури, потік функцій) або ж - як взаємовідношення (ієрархія) внутрішніх і залежних між собою функціональних дій, які забезпечують зміну станів використовуваних ресурсів та створення певної продукції, що має цінність для клієнта. Разом з тим, занадто узагальненим і нечітким вважаємо запропоноване В. Алькемою визначення бізнес-процесу як «...сукупності послідовних, взаємопов'язаних, систематично здійснюваних дій у рамках реалізації стратегії розвитку, спрямованих на формування та використання потенціалу в ході здійснення певного виду діяльності з метою створення конкурентоспроможної продукції (послуг, робіт), здатної задовольняти зовнішніх і внутрішніх споживачів й забезпечити комапанії досягнення стратегічних цілей в умовах динамічного ринкового середовища» [2]

Класичним вважається визначення бізнес-процесу у викладі його М. Портером або ж М. Хаммером та Дж.Чампі як «...сукупності різних видів діяльності, в межах якої на вході існує один або більше видів ресурсів, а на виході, як результат, створюється продукт, що становить цінність для споживача» [15]. Але, на наш погляд, найбільш прийнятними для розуміння терміну «бізнес-процес» $є$ десрініції X. Харінгтона, який визначає бізнес-процес як «...логічний, взаємозалежний набір заходів суб'єкта, що споживає ресурси, створює додаткову вартість і видає результат кінцевому замовнику або споживачу» [16] та А.-В. Шеєра - як «...пов'язаний набір повторюваних дій, які перетворюють вхідний матеріал i/aбо інформацію в кінцевий продукт (послугу) у відповідності з заздалегідь встановленими правилами [17]. У цьому контексті можна погодитись з авторами [10], що бізнес-процес являє собою сукупність бізнес-операцій, певну логічно взаємопов'язану множину внутрішніх видів діяльності, які починаються 3 одного або більше входів та закінчуються досягненням заданого результату (зокрема - створенням продукції чи її реалізацією). При цьому зміст зазначених видів діяльності (бізнесоперацій), як стверджує О. Данченко [13], визначається конкретними цілями і функціями підприємства та передбачає подальший розподіл зазначених дій і відповідальності між окремими виконавчими ланками (структурними підрозділами) і конкретними працівниками. Таким чином, під бізнес-процесом, на нашу думку, потрібно розуміти сукупність взаємопов'язаних видів діяльності, робіт, дій чи операцій, які за заздалегідь встановленими правилами і визначеними методиками та алгоритмами на основі логічного розподілу зазначених дій і відповідальності між окремими виконавчими ланками та конкретними працівниками забезпечують реалізацію окремих функцій чи досягнення визначених цілей підприємства шляхом трансформації використовуваних ресурсів у результат (продукція, послуги, зміна стану предметів праці тощо), що має цінність для клієнта.

Вважаємо, що ключовими для бізнес-процесу елементами є: 1) ресурси (які в кібернетичній моделі управління бізнес-процесами (рис. 1) традиційно виступають як «вхід»); 2) логічно і функціонально взаємопов'язані виробничі та управлінські дії (операції) 3 трансформації зазначених ресурсів («процесор» - сукупність підпроцесів, робіт, операцій, здійснюваних над входами для отримання виходів, тобто - для реалізації визначеної функції); 3) результат (продукція, послуги - «вихід»)); поряд 3 цим, суб'єктом управління бізнес-процесом виступають виконавці («власники БП») - відповідальні за бізнес-процес, діяльність яких в згаданій кібернетичній моделі позначається як «управлінський вплив». 


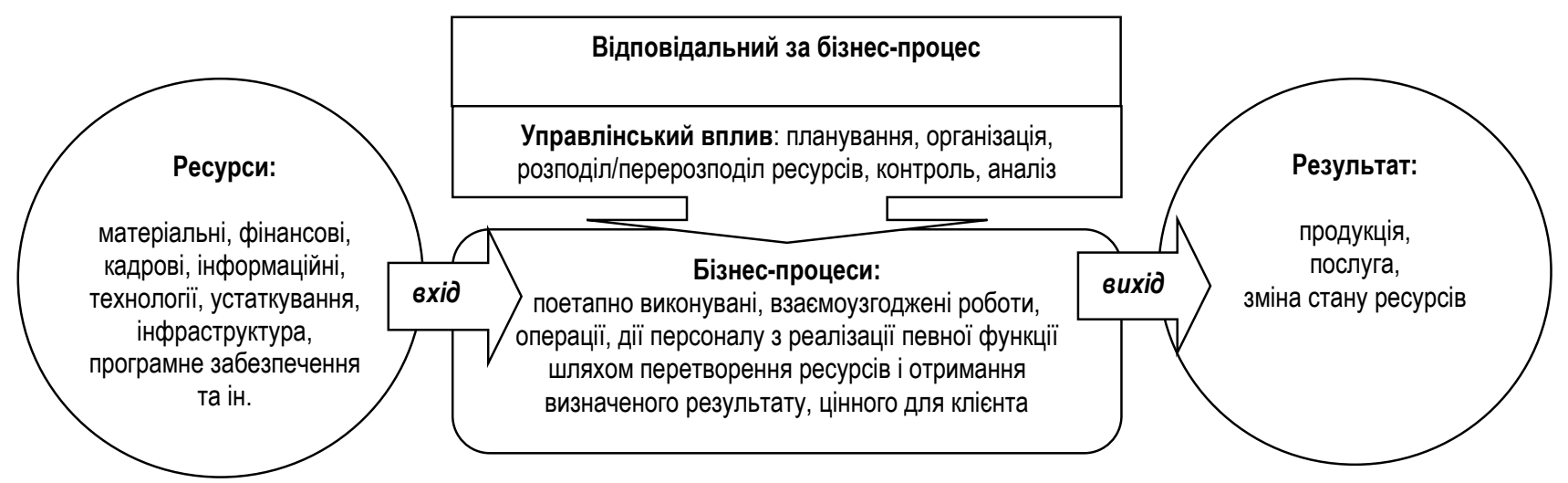

Рис. 1. Принципова модель управління бізнес-процесами

3 наведеної схеми зрозуміло, що для кожного з цільових завдань компанії, які формулюються як певна функція діяльності підприємства, як заданий результат реалізації цієї функції, підбираються різні ресурси (вхід) та обираються й виконуються уповноваженими працівниками відповідним чином упорядковані процедури, алгоритми, комплекси робіт, дій, операцій, що забезпечують трансформацію ресурсів у результат (вихід). Ключову роль в реалізації даної моделі відіграє якість управління бізнес-процесами, яке В. Алькема [2] пропонує визначати як цілеспрямовану діяльність суб'єктів управління з використанням сукупності методів і засобів впливу на об'єкти управління для досягнення поставлених стратегічних цілей. Разом з тим, управління бізнес-процесами суттєво ускладнюється тим, що для реалізації визначеного завдання (певної конкретної функції) підприємство може застосовувати різні ресурси, різні способи організації виробничих і невиробничих операцій зі створення споживчої вартості, різні технології чи різні способи взаємодії персоналу або структурних підрозділів, що формує структуру відповідного бізнес-процесу, результативність та ефективність їх здійснення може істотно відрізнятись в частині тривалості виробничого циклу, гнучкості підприємства на споживчому ринку тощо. Варто також зазначити, управління різними бізнес-процесами підприємства може здійснюватися відокремлено, під управлінням різних власників конкретних бізнес-процесів, проте в кінцевому підсумку всі бізнес-процеси підприємства мають бути підпорядковані єдиній меті (цілям) даного суб'єкта господарювання.

Управління бізнес-процесами підприємства, за визначенням В. Алькеми [2], є «...складним процесом вироблення й реалізації суб‘єктом управління управлінських рішень щодо забезпечення високого рівня їх (бізнес-процесів) ефективності, що відображається в результатах діяльності компанії та задоволеності споживачів». У зв'язку з цим для реального втілення завдань управління бізнес-процесами наведена вище модель має бути деталізована шляхом розробки під керівництвом відповідальної за кожен конкретний бізнес-процес особи карти бізнес-процесу, основними елементами якої вважаються: найменування бізнес-процесу, його мета, контрольовані параметри, методи вимірювання цих параметрів, показники результативності бізнес-процесу, його текстовий опис, внутрішні бізнес-процеси (бізнес-процеси нижчого порядку), найменування власника бізнес-процесу, входи, функції та виходи бізнес-процесу, переліки вхідних, вихідних і регламентуючих документів, підрозділів і посад, задіяних в даному бізнес-процесі. Наявність такої карти по кожному бізнес- процесу дозволяє не лише детально описати весь комплекс діяльності підприємства, але й відобразити та розуміти взаємодію між різними підрозділами і виконавцями (що саме, кому і для чого передається чи приймається на певному етапі), проводити аналіз кожної операції, виявляти і вирішувати наявні проблеми, визначати причинно-наслідкові зв'язки, місце і час їх виникнення, а також відповідальну особу чи підрозділ, з вини якого дана проблема виникла [18].

Завдяки цьому процесний підхід в управлінні якісно переважає функціональний, адже його запровадження забезпечує наочність, чіткість, зрозумілість процесів діяльності підприємства, підвищує гарантії забезпечення якості продукції (послуги) і зниження витрат на досягнення завдань управління якістю, відображає логічність групування робіт і операцій відповідно до визначеної цілі їх виконання, розмежовує зони та сфрери відповідальності між окремими підрозділами (i окремими категоріями виконавців), дозволяє вибудувати сукупність всіх бізнес-процесів підприємства з врахуванням їх видової диференціації, ієрархічного співвідношення та сфери реалізації.

В контексті останнього звернемо увагу на існуванні різниці в питаннях організації бізнес-процесів та управління ними залежно від сфери діяльності підприємства, зокрема виробничої та сфери обігу. Так, суттєвою проблемою для підприємств торгівлі $€$ той факт, що науково-теоретичні засади та прикладні рекомендації щодо впровадження у торговельну практику ідей та інструментарію процесно-орієнтованого управління базуються на наукових положеннях і досвіді діяльності підприємств виробничої сфери, а це об'єктивно зумовлює певні ускладнення з реалізацією даного інструментарію. Основною причиною цього вважаємо недостатню теоретичну визначеність із видовим різноманіттям бізнес-процесів підприємств торгівлі, їх змістом і структурою.

Базовим для вирішення цієї проблеми є питання загальної класифікації бізнес-процесів, яка до цього часу не набула єдиного загальновизнаного вигляду, внаслідок чого різні автори виділяють бізнес-процеси: основні, допоміжні та забезпечуючі; основні, супутні, допоміжні та забезпечуючі, БП управління та БП розвитку; операційні, підтримуючі та управлінські; внутрішні і зовнішні; вхідні, вихідні; типові, специфічні, наскрізні; первинні і вторинні; верхнього, середнього та нижнього рівня та ін. [1]. Наведений перелік не є вичерпним, адже в цій же праці, присвяченій управлінню бізнес-процесами підприємств оптової торгівлі, автор виділяє бізнес-процеси типові (маркетингові, логістичні, обслуговування споживачів) та вторинні (підтримуючі, управлінські), виробничо-технологічні, 
маркетингові, логістичні, інформаційні, фінансові та БП управління персоналом, а також - інноваційні бізнес-процеси [1]. Натомість, А. Носуліч [19] розглядає діяльність оптового торговельного підприємства як поєднання комерційних бізнес-процесів із закупівель товарів та надання послуг постачальникам, комерційних бізнес-процесів із реалізації товарів і надання послуг оптовим покупцям, підтримку яких забезпечують т.зв. виробничо-логістичні та фінансові бізнес-процеси. В той же час, в роботі О. Ольшанського [20] запропоновано поділ бізнес-процесів підприємств торгівлі на :

- основні БП (аналіз ринку і потреб споживачів; розроблення асортиментної політики та управління асортиментом; управління закупівлями і логістика; управління складуванням та зберіганням товару; управління виробничими операціями; управління процесом реалізації товарів та обслуговування споживачів; управління післяпродажним та гарантійним обслуговуванням);

- допоміжні БП (управління людськими ресурсами; управління інформаційними ресурсами; управління фінансовими і просторовими ресурсами; управління матеріально-технічними ресурсами; управління комунікаційними зв'язками; управління поліпшеннями та змінами);

- БП розвитку (впровадження інноваційних комунікаційних технологій управління; впровадження ресурсозберігаючих, наукомістких технологій; модернізація магазинів; впровадження сучасних методів продажу товарів та обслуговування споживачів);

- забезпечуючі БП (система менеджменту якості; організаційна структура управління підприємством; система методів прийняття управлінських рішень; система мотивації та заохочення працівників).

Проведений аналіз засвідчив відсутність єдиної стандартизованої системи бізнес-процесів підприємств торгівлі, а тому залежно від специфіки власного бізнесу підприємствам торгівлі доцільно на основі найбільш поширених зразків класифікації розробляти власну типологію бізнес-процесів, адаптовану для потреб створення ефективного механізму управління підприємством.

Зокрема, об'єктом невідкладного аналізу, на наш погляд, має стати термін «логістичні бізнес-процеси», який у трактуванні Т. Лазоренко [6] означає «...сукупність процесів, що забезпечують організацію руху товарно-матеріальних цінностей: від закупівлі ресурсів та виробництва готової продукції до їх подальшої реалізації споживачам або торговим партнерам». Разом з тим, саме в такій редакції дане визначення $€$ занадто узагальненим, стосується в більшій мірі логістичного ланцюга і при цьому не відображає специфріки логістичної діяльності підприємств торгівлі.

В той же час, у наведених вище класифікаціях бізнеспроцесів на прикладах підприємств торгівлі термін «логістичний бізнес-процес» використовується авторами для позначення бізнес-процесів, які відрізняються за реалізовуваними функціями, за рівнем зв'язку з основним системоутворюючим для системи логістики підприємства торгівлі потоком - товарним, цільовими завданнями підрозділів-власників бізнес-процесів, за декларованими цілями бізнес-процесу та за його місцем в системі управління підприємством.

Так, на наш погляд, найбільшою проблемою у віднесенні бізнес-процесів підприємств до категорії логістичних $€$ використання для надання статусу логістичного практично всім бізнес-процесам підприємств, в управлінні яких використовуються т.зв. логістичний підхід і логістичні стратегії. В цьому випадку логістичний бізнес-процес у працях В. Алькеми [2], І. Кривов'язюка і Ю. Кулика [4], О. Солодкої [11] трактується як «...взаємопов'язана сукупність операцій і функцій, що переводять ресурси компанії (при управлінні товарними і супутніми потоками) в результат, що задається логістичною стратегією фірми. Отже, логістичні бізнес-процеси - це процеси, які зосереджені на плануванні руху матеріалів, закупівлі, виробництві і поставці товарів споживачам». Логіка такого підходу відображена в наступному: «Зважаючи на те, що об'єктом логістичного управління є потоки, потокові процеси, будь-які процеси, що пов'язані з переміщенням будьчого, управління логістичними бізнес-процесами компанії можна визначити як інтегроване управління бізнес-процесами з просування продукції і супутніх потоків від джерела їх виникнення до кінцевого споживача з метою досягнення максимальної ефективності діяльності компанії» [11]. Вважаємо, що «планування виробництва» чи «управління розробкою продукції та доведенням ії до комерційного стану» у коментарі до наведеної дефрініції не зовсім прийнятні для визначення даного бізнес-процесу як логістичного, адже цільовою функцією даного бізнес-процесу є управління виробництвом та забезпечення його ефективності.

Також складно погодитись із представленням як логістичних всього комплексу бізнес-процесів логістичних компаній (перевізників, експедиторів, транспортно-логістичних центрів, терміналів тощо): «...бізнес-процес у логістичній діяльності - це сукупність послідовних, взаємопов'язаних систематично здійснюваних дій у рамках реалізації стратегії розвитку, спрямованих на формування та використання логістичного потенціалу в ході здійснення трансформацій матеріального потоку 3 метою створення конкурентоспроможних послуг, здатних задовольняти зовнішніх і внутрішніх споживачів й забезпечити компанії досягнення стратегічних цілей в умовах динамічного логістичного середовища» [2]. Вважаємо, що попри повну залученість таких підприємств до діяльності в сфері логістики, реально бізнес-процеси в них забезпечують реалізацію не лише логістичної функції, пов'язаної з перевезеннями, тимчасовим зберіганням, завантажувально-розвантажувальними роботами та виконанням інших логістичних операцій, але й аналітичною та управлінською діяльністю, управлінням персоналу, юридичним забезпеченням тощо.

В цьому сенсі подібною логікою, що базується на тісноті зв'язку бізнес-процесів з виконанням логістичних функцій в системі основної діяльності суб'єкта господарювання, доцільно керуватися для визначення сутності логістичних бізнес-процесів підприємств торгівлі. Справа в тому, що функціонування торговельного підприємства підпорядковується досягненню цілей основної функції будь-якого підприємства торгівлі - реалізації власних економічних інтересів (отриманню цільового розміру прибутку) шляхом систематичного здійснення купівлі-продажу товарів оптовими або роздрібними покупцями для задоволення їх різноманітних індивідуальних чи виробничих потреб, а також надання супутніх послуг. Відповідно, функціонування торговельного підприємства забезпечується насамперед шляхом проведення комерційної роботи, спрямованої на визначення найбільш привабливого для потенційних покупців асортименту товарів 
та оптових закупівель таких товарів з різних джерел і від різноманітних постачальників з подальшою реалізацією товарів (оптовими партіями чи вроздріб) оптовим покупцям або індивідуальним споживачам, у поєднанні з виконанням комплексу робіт із збереження товарної маси, управління товарними запасами та доведення товарної маси до кожного пункту продажу, які за своїм характером відносяться до логістичних операцій. Саме ці роботи в аспектах їх планування, організації та реалізації забезпечують виконання виробничо-логістичної функції торговельного підприємства i, відповідно, мають розглядатися як центральний складовий елемент (процесор) відповідних бізнес-процесів. Поряд з цим, як показано одним з авторів цієї статті [21], комплекс логістичних операцій виступає як необхідне забезпечення для виконання комерційних операцій із закупівель оптових партій товарів та їх оптового або роздрібного продажу, а також для обслуговування споживачів у частині логістичного сервісу. Тому, на наш погляд, до категорії логістичних бізнеспроцесів підприємств торгівлі потрібно відносити ті з них, процесором в яких виступають логістичні операції з товарним та/або інформаційним потоком, які здійснюються в межах реалізації комерційної та логістичної функції підприємства торгівлі у відносинах з виробниками, постачальниками, логістично-розподільчими центрами, регіональними складами і терміналами, клієнтами-покупцями та передбачають управління такими компонентами «логістичного міксу» («logistics mix»), як: складські споруди; запаси; комплектування та паковання; транспортування; зв'язок тощо. При цьому конкретний перелік логістичних бізнес-процесів підприємств торгівлі може варіювати залежно від виду торговельної діяльності (оптова, дрібнооптова, оптово-роздрібна, роздрібна торгівля), рівня спеціалізації і товарного профілю (напр., спеціалізована, універсальна торгівля, торгівля змішаним асортиментом товарів), масштабів торговельної діяльності, прийнятої організаційної структури підприємства торгівлі, формату торговельного об'єкта та ін.; більше того, зазначені переліки можуть формувати складні ієрархічні схеми з каскадуванням бізнес-процесів та їх підпорядкуванням.

На наш погляд, найбільш загальний перелік логістичних бізнес-процесів для підприємств оптової торгівлі має включати такі типові бізнес-процеси, як «Управління закупівлями», «Управління запасами», «Управління оптовими продажами (збутом)», «Управління складами та технологічними процесами зберігання товарів», «Управління транспортуванням», «Управління інформаційними потоками»; в той же час, для підприємств роздрібної торгівлі, в яких організаційні структури, як правило, є більш спрощеними, цей перелік може охоплювати бізнес-процеси «Управління закупівлями», «Управління зберіганням і внутрішньома- газинними технологічними процесами», «Управління транспортуванням», «Управління реалізацією товарів». Надалі кожен 3 цих бізнес-процесів 3 врахуванням індивідуальних особливостей підприємства, організації і механізмів управління, складу управління та виконавців, організації логістичної діяльності може бути уточнений, скоригований, дезагрегований на підпорядковані бізнес-процеси: напр., логістичний бізнес-процес «Управління зберіганням і внутрішньомагазинними технологічними процесами» може бути скомпонований 3 таких функціональних блоків, як приймання товарів, розміщування товарів у зонах зберігання, інвентаризація, передпродажна підготовка товарів, переміщування товарів у торговий зал та ін.; в той же час для підприємства роздрібної торгівлі мережевого типу зазначений бізнес-процес може бути трансформований шляхом виведення за організаційні межі магазинів і передавання в компетенцію логістичного центру такого функціонального блоку, як «Управління зберіганням товарів». Натомість практично відсутні реальні можливості для виділення логістичних бізнес-процесів на підприємствах торгівлі, які функціонують на засадах суб'єктів малого чи мікропідприємництва, в яких застосовуються найпростіші організаційні моделі, а чисельність працівників зумовлює залучення їх одночасно до виконання робіт, необхідних для реалізації різних комерційних і логістичних фрункцій торговельного підприємства.

Разом 3 тим, діяльність з управління бізнес-процесами підприємств торгівлі лише ідентифікацією групи логістичних бізнес-процесів і формуванням їх переліку для конкретних торговців не завершується, а має бути продовжена такими важливими заходами з впровадження процесного підходу, як регламентація бізнес-процесів та формування системи основних показників результативності та есрективності кожної групи (включно з логістичними) бізнеспроцесів.

Висновки. Проведений аналіз дозволив уточнити сутність процесного підходу та його ключового поняття - «бізнес-процес», на основі побудованої моделі управління бізнес-процесами виявити ключову роль виконуваної в межах бізнес-процесу функції як системоутворюючого елемента, котрий також може бути використаний для виокремлення логістичних бізнес-процесів із загального різноманіття бізнес-процесів підприємств торгівлі. За результатами аналізу авторами запропоновано типові переліки логістичних бізнес-процесів для різних видів підприємств торгівлі та визначено необхідність їх регламентації задля впровадження у вітчизняну управлінську практику. Подальші дослідження рекомендується проводити в напрямку формування системи показників оцінювання результативності та ефективності окремих функціональних груп бізнес-процесів з врахуванням специфіки і масштабів торговельної діяльності в оптовій та роздрібній торгівлі.

\section{Список використаної літератури:}

1. Ільченко Н. Б. Управління бізнес-процесами на підприємстві оптової торгівлі : дис. ... докт. екон. наук : 00.08 .04 економіка та управління підприємствами (за видами економічної діяльності). К. : КНТЕУ, 2017. 521 с.

2. Алькема В. Г. Реінжиніринг бізнес-процесів логістичного комплексу компанії. Вчені записки Університету «КРОК». 2019. №2 (54). C. 126-136.

3. Бойко Н.І., Лавренюк С. В. Управління логістикою бізнес-процесів підприємства за допомогою технології «Workflow». Торгівля, комерція, підприємництво : зб. наук. праць. Львів : Вид-во ЛКА, 2008. -С. 63-65.

4. Кривов'язюк І. В., Кулик Ю. М. Реінжиніринг логістичних бізнес-процесів і систем як основа їх самовдосконалення та розвитку URL: http://economics.opu.ua/ files/archive/2013/No2/87-94.pdf

Вісник Сумського національного аграрного університету 
5. Крикавський Є. В. Логістичне управління : підруч. Львів : Вид-во Нац. ун-ту «Львівська політехніка», 2015. 683 с.

6. Лазоренко Т. В. Концептуальні засади організації управління бізнес-процесами сучасних логістичних систем. Науковий вісник Ужгородського національного університету. 2019. Вип. 23, ч. 1. С. 147-151.

7. Ольшанський О. В. Особливості управління бізнес-процесами підприємств торгівлі та методи їх удосконалення. Науковий вісник Ужгородського національного університету. 2018. Вип. 22, ч. 3. С. 22-26.

8. Павловський П. В. Формування системи логістичних бізнес-процесів переробної галузі : дис. ... канд. екон. наук : 00.08.03 - економіка та управління народним господарством. Краматорськ, 2018. 226 с.

9. Петрова А. В. Управление логистическими системами предприятий розничной торговли на основе процессного подхода : автореф. дис. ... канд. экон. наук : 08.00.05 - Экономика и управление народным хозяйством (логистика). Екатеринбург, 2008. $28 \mathrm{c}$.

10. Поповиченко І. С., Подалюк М. Р., Горєла В. Д. Управління результативністю та ефективністю бізнес-процесів підприємства на основі застосування логістичного підходу. Східна Європа: економіка, бізнес та управління. 2018. Вип. 1 (12). С. 223-226.

11. Солодка О. В. Реінжиніринг логістичних бізнес-процесів як спосіб їх вдосконалення. Вісник Національного університету «Львівська політехніка». 2010. № 669. С. 317-322.

12. Фролова Л. В. Механізми логістичного управління торговельним підприємством : монографія. Донецьк : ДонДУЕТ, 2005. 322 c.

13. Данченко О. Б. Практичні аспекти реінжинірингу бізнес-процесів. К. : Університет економіки та права «КРОК», 2017. $238 \mathrm{c}$.

14. Стандарт 10 ISO 9001:2000 «Управління бізнес-процесами». Системи управління якістю. Вимоги: ДСТУ ISO 9001:2001. К. : Держстандарт України, 2001. 13 c.

15. Hammer M., Champy J. Reengineering the Corporation. A Manifesto for Business Revolutions. Harper Business, 1993. $223 p$. 1991. $274 \mathrm{p}$

16. Harrington H. J. Business process improvement: the breakthrough strategy for total quality and productivity. McGrawHill,

17. Шеер А. В. Бизнес-процессы. Основные понятия. Теория. Методы. М. : Весть-МетаТехнология, 1999. 151 с.

18. Ітченко Д. М., Сидоренко А. В. Реінжиніринг логістичних бізнес-процесів як дієвий механізм їх реорганізації. Регіональна економіка та управління. 2018. № 4 (22). С. 38-43.

19. Носуліч А. М. Процесний підхід до побудови механізму оптової торговельної діяльності. 2010. № 3. URL : http://www.economy.nayka. com.ua/?op=1\&z=158

20. Ольшанський О. В. Розроблення структури та класифрікації бізнес-процесів підприємств торгівлі. Економіка і суспільство. -2018. Вип. 19. С. 544-547.

21. Міщук І. П. Формування систем логістики підприємств торгівлі: теорія і практика : монографія. Львів : Вид-во ЛКА, 2015. 452 c.

References:

1. Ilchenko, N. B. (2017). Upravlinnya biznes-protsesamy na pidpryyemstvi optovoyi torhivli [Management of business processes at the enterprise of wholesale trade]. Diss.: 00.08.04. K.

2. Alkema, V. G. (2019). Reinzhynirynh biznes-protsesiv lohistychnoho kompleksu kompaniyi [Reengineering of business processes of the logistics complex of companies]. Vcheni zapysky Universytetu «KROK» - Introduced records KROK University, 2 (54), 126-136

3. Boyko, N. I., Lavreniuk, S. V. (2008). Upravlinnya lohistykoyu biznes-protsesiv pidpryyemstva za dopomohoyu tekhnolohiyi «Workflow» [Management of logistics business process for the company "Workflow"]. Torhivlya, komertsiya, pidpryyemnytstvo Trade, commerce, entrepreneurship, 9, 63-65.

4. Krivovyazjuk I. V., Kulyk J. M. (2013). Reinzhynirynh lohistychnykh biznes-protsesiv i system yak osnova yikh samovdoskonalennya ta rozvytku [Reengineering of logistic business-processes and systems as the basis of their selfimprovement and development]. Available at: http://economics.opu.ua/files/archive/2013/No2/87-94.pdf

5. Krykavsky, E. V. (2015). Lohistychne upravlinnya [Logistic management]. Lviv: Lviv National Polytechnic University.

6. Lazorenko, T. V., Do Thi Minh Thao (2019). Kontseptual'ni zasady orhanizatsiyi upravlinnya biznes-protsesamy suchasnykh lohistychnykh system [Conceptual principles of organization of business process management of modern logistics systems]. Naukovyy visnyk Uzhhorods'koho natsional'noho universytetu - Scientific Bulletin of Uzhgorod National University, 23(1), 147-151.

7. Olshansky, O. V. (2018). Osoblyvosti upravlinnya biznes-protsesamy pidpryyemstv torhivli ta metody yikh udoskonalennya [Special management of business processes of trade and methods of their implementation]. Naukovyy visnyk Uzhhorods'koho natsional'noho universytetu - Scientific Bulletin of Uzhgorod National University, 22(3), 22-26.

8. Pavlovsky, P. V. (2018). Formuvannya systemy lohistychnykh biznes-protsesiv pererobnoyi haluzi [Formation of systems of logistic business processes of the processing company]. Ph.D. diss.: 00.08.03. Kramatorsk.

9. Petrova, A. V. (2008). Upravlenye lohystycheskymy systemamy predpryyatyy roznychnoy torhovly na osnove protsessnoho podkhoda [Management of logistics and system enterprises of retail trade on the basis of technological approach]. Ph.D. Thesis: 08.00.05. Ekaterinburg.

10. Popovychenko, I. S., Podalyuk, M. R., Gorela, V. D. (2018). Upravlinnya rezul'tatyvnistyu ta efektyvnistyu biznes-protsesiv pidpryyemstva na osnovi zastosuvannya lohistychnoho pidkhodu [Management worked and worked effectively at the enterprise, using 
a logistic approach]. Skhidna Yevropa: ekonomika, biznes ta upravlinnya - Eastern Europe: economics, business and management, 1(12), 223-226.

11. Solodka, O. V. (2010). Reinzhynirynh lohistychnykh biznes-protsesiv yak sposib yikh vdoskonalennya [Reengineering of logistics business processes as their improvement]. Visnyk Natsional'noho universytetu "L'vivs'ka politekhnika» - Bulletin of Lviv National Polytechnic University, 669, 317-322.

12. Frolova, L. V. (2005). Mekhanizmy lohistychnoho upravlinnya torhovel'nym pidpryyemstvom [Mechanisms of logistic management of trade ownership]. Donets'k : DonDUET.

13. Danchenko, O. B. (2017). Praktychni aspekty reinzhynirynhu biznes-protsesiv [Practical aspects of business process reengineering]. K.: University of Economics and Law "KROK". 238 p.

14. Standard 10 ISO 9001: 2000 "Business Process Management" (2001). Quality management systems. Requirements: DSTU ISO 9001: 2001. K.

15. Hammer, M., Champy, J. (1993). Reengineering the Corporation. A Manifesto for Business Revolutions [Reengineering the Corporation. A Manifesto for Business Revolutions]. Harper Business.

16. Harrington, H. J. (1991). Business process improvement: the breakthrough strategy for total quality and productivity [Business process improvement: the breakthrough strategy for total quality and productivity]. McGrawHill.

17. Scheer, A.W. (1999). Byznes-protsessy. Osnovnye ponyatyya. Teoryya. Metody [Business processes. Basic concepts. Theory. Methods]. M.: Vest-MetaTehnologiya. $151 \mathrm{p}$.

18. Itchenko, D. M., Sidorenko, A. V. (2018). Reinzhynirynh lohistychnykh biznes-protsesiv yak diyevyy mekhanizm yikh reorhanizatsiyi [Reengineering of logistics business processes as existing enterprises of their reorganization]. Rehional'na ekonomika ta upravlinnya - Regional economy and management, 4 (22), 38-43.

19. Nosulich, A. M. (2010). Protsesnyy pidkhid do pobudovy mekhanizmu optovoyi torhovel'noyi diyal'nosti [The process of approach to the built company of wholesale trade]. Efektyvna ekonomika - Effective economy, 3. Available at: http: //www.economy.nayka. com.ua/?op=1\&z=158

20. Olshansky, O. V. (2018). Rozroblennya struktury ta klasyfikatsiyi biznes-protsesiv pidpryyemstv torhivli [Development and classification of business processes of trade enterprises]. Ekonomika i suspil'stvo - Economy and public, 19, 544-547.

21. Mishchuk, I. P. (2015). Formuvannya system lohistyky pidpryyemstv torhivli: teoriya i praktyka [Forming of logistics systems of trade enterprises: theory and practice]. Lviv: LCA Publishing House, 452 p.

Mishchuk Ihor Pylypovych, Dr of Economics, Associate Professor, Lviv University of Trade and Economics (Lviv, Ukraine)

Marii Olga Tarasivna, PhD student, Lviv University of Trade and Economics (Lviv, Ukraine)

Management of logistic business processes of trade enterprises: problems of theory and practice

The article is devoted to the issues of theoretical generalization and clarification of the essence and content of logistic business processes of trade enterprises, as well as the formulation of some practical recommendations for improving the management of logistic business processes of trade enterprises. The need to build a comprehensive, appropriately organized and structured system of interconnected and connected with the external economic environment logistic business processes of each (including - trade) enterprise is emphasized.Insufficient formation of the theoretical basis on the issue of the essence of logistic business processes of enterprises, their features in trade enterprises and the development of mechanisms of so-called. logistic management. The analysis revealed the presence of contradictions in the interpretation of the concept of "logistic business processes", as well as differences in species diversity, content and methods of implementation of logistic business processes of wholesale and retail trade.Based on the essence of the term "process" in economic activity, a refined author's interpretation of the business process is proposed, as well as an original basic model of business process management. The key role of the category "function of the enterprise's activity" in the formation of the typology of business processes of enterprises, in particular - trade, is proven. The objective validity and expediency of allocating a group of logistic business processes in the array of business processes of trade enterprises, which have independent significance or provide logistical support for the implementation of commercial functions of a wholesaler or retailer, has been established. The approaches of some scientists to the classification of business processes of trade enterprises are analyzed, the essence and features of logistic business processes of trade enterprises are specified. The need for clear identification and regulation of logistic business processes of trade enterprises is emphasized, author's recommendations for the formation of a list of logistic business processes, taking into account the type and scale of trade activities of the business entity, are formulated.

Key words: trade enterprise, process approach, business processes, logistic function, logistic business process, business process management model

Дата надходження до редакції: 17.11.2019 р. 